\title{
EVALUATION OF GLUTAMINE COMBINED WITH TOPICAL CORTICOSTEROIDS IN THE TREATMENT OF EROSIVE ORAL LICHEN PLANUS
}

\author{
Marwa M. Gebril ${ }^{* *} B D S$, Eglal M. Moussa² $P h D$, Hanaa S. Raslan ${ }^{3} P h D$
}

\begin{abstract}
INTRODUCTION: Lichen planus (LP) is an inflammatory skin disease of unknown etiology. Increased oxidative stress has been implicated in the pathogenesis of erosive oral lichen planus (EOLP). Glutamine (Gln) is a source of energy for fibroblasts, immunocompetent cells, and intestinal epithelial cells involved in collagen production. It promotes protein and collagen synthesis, imparts immunity, and maintains the alimentary canal mucosa structure.

OBJECTIVES: The aim of this study was to evaluate the effect of Glutamine combined with topical corticosteroid in the treatment of erosive OLP.

MATERIALS AND METHODS: This randomized, parallel, controlled clinical study was conducted on thirty patients with a confirmed clinical and histopathological diagnosis of OLP who were randomly divided into two groups. Group 1 treated with topical steroids plus antifungal; Group 2 treated with Glutamine combined with topical steroids plus antifungal. Subjective symptoms and Visual Analogue Scale (VAS) were recorded at base line, after one month and at three months. The objective sign clinical score was recorded at baseline, one and three months post-treatment.

RESULTS: Both groups showed decrease in lesion size and symptoms of OLP. The glutamine treated group showed a significantly higher decrease in pain score in comparison to the corticosteroid treated group. Regarding the healing score, there was no statistically significant difference between the two groups.

CONCLUSIONS: Glutamine as adjunctive to topical corticosteroid is effective in the treatment of EOLP; it resulted in a decrease in symptoms of the disease and more control of pain when compared to the conventional therapy. However, it has no effect on the signs of the disease.
\end{abstract}

KEYWORDS: Erosive oral lichen planus, Glutamine, Lichen planus.

1- BDS, Faculty of Dentistry, Alexandria University, Alexandria, Egypt.

2- Professor of Oral Medicine, Periodontology, Oral Diagnosis and Radiology Department, Faculty of Dentistry, Alexandria University, Alexandria, Egypt

3- Professor of Oral Pathology, Faculty of Dentistry, Alexandria University.

* Corresponding author:

E-mail:moooor89@yahoo.com

\section{INTRODUCTION}

Lichen planus (LP) is a chronic, inflammatory, immunological and mucocutaneous disease that affects mainly the stratified squamous epithelia (1). Cutaneous lichen planus (CLP) causes itching and undergoes spontaneous remission, while oral lichen planus (OLP), may persist up to 20 years without remission and is frequently premalignant $(2,3)$.

Most therapies of OLP are mainly symptomatic and the precise etiology is still unknown. Several factors have been implicated in the etiology of this condition such as: genetic background, autoimmunity, immunodeficiency, stress and infectious agents $(1,4-6)$. Studies have suggested that it is a chronic T-cell mediated, autoimmune damage to basal keratinocytes of the oral mucosa (7). Furthermore, studies have reported an increased oxidative stress and lipid peroxidation in patients with oral lichen planus $(8,9)$.

Studies support the concept that OLP lesions often appear after an episode of intense emotional stress and the disease frequently undergoes remissions and exacerbations that clearly relate to the patients' emotional status (10). Several researchers have also reported higher prevalence of mixture of anxiety, depression, panic symptoms, social phobia and obsessive thoughts in patients with lichen planus $(11,12)$.

Glutamine (Gln) is a non-essential amino acid during normal conditions, which becomes essential during periods of stress, rapid growth or critical illness (13). It is considered a potent inducer of Heat Shock Proteins (HSP) in times of stress, injury or illness (14).

It, therefore, seems beneficial to assess the clinical evidence supporting the use of antioxidants specifically in lichen planus. If shown to be effective, antioxidants may act as a safe alternative to long-term use of nonsteroidal antiinflammatory drugs or treatment by other medications that are associated with adverse effects (15).

\section{MATERIALS AND METHODS \\ Participants and Study design:}

This randomized, parallel, controlled clinical trial was conducted on thirty patients with clinical and histological diagnosis of erosive oral lichen planus who were recruited from the outpatient clinic of the Department of Oral Medicine, Periodontology, Diagnosis and Radiology, Faculty of Dentistry, Alexandria University. The study was approved by the Research Ethics committee of the Faculty of Dentistry, Alexandria University (IRB NO: 00010556) (IORG 0008839)/6-11-2016. All patients signed an informed consent form to participate in this study after being advised of the nature of the study. Patients were divided into two equal groups. The control group included fifteen patients with erosive OLP who were managed by topical corticosteroid ointment trimicolone acetonide (kenacort) plus antifungal (Miconazole oral gel). The test group included fifteen patients with erosive OLP who were managed by Glutamine therapy in combination with a 
topical corticosteroid (Kenacort in orabase) plus antifungal (Miconazole oral gel).

- Topical corticosteroid applied two to three times a day the first three weeks followed by tapering the following nine weeks until a maintenance dose of two to three times a week was reached (Triamcinolone Acetonide ointment $5 \mathrm{gm}$, Kenacort-A orabase Pomad, Deva Holding A.S., Istanbul, Turkey) (16).

- Topical antifungal was applied three to four times daily for three weeks (Miconaz oral gel, MUP Medical Union Pharmaceuticals) (17).

- Glutamine capsules (for systemic use) were given in a dosage of one capsule $(750 \mathrm{mg}=0.75 \mathrm{~g}$ ) three times daily (2.25g/day) on an empty stomach for one month. The active ingredients in each capsule include: L-Glutamine $750 \mathrm{mg}$, L-Taurine 50 mg, Vitamin B6 Pyridoxine Hydrochloride1.3 mg, Vitamin B1 Thiamine $\mathrm{HCl} 1.2 \mathrm{mg}$ and Zinc 1m (HI PHARM, El-Obour City, Egypt) (18).

\section{Inclusion Criteria}

1-Patients clinically and histopathologically diagnosed to be suffering from EOLP (19).

2-Patients who had symptoms i.e. pain and/or burning sensation secondary to EOLP (20).

3-Patients under stressful life conditions as evidenced by ISMA-UK Stress Questionnaire (21).

4-Males and Females with an age ranging from 30-60 years Exclusion Criteria

1-Patients suspected to have lichenoid drug reaction or lichenoid contact allergy.

2-Patients suffering from any systemic diseases (such as diabetes, cardiovascular or liver disorder, renal dysfunction)

3-Patients with findings of any physical or mental abnormality which would interfere with or be affected by the study procedure.

4-Patients who have adverse habits of chewing tobacco and with smoking.

5-Pregnant and lactating women.

6-Patients under treatment of corticosteroid and immunosuppressant.

7-Patients exhibiting dysplastic changes within histopathological evaluation.

\section{Randomization, blinding and allocation concealment}

Subjects fitting the inclusion criteria were randomly assigned using a computer- generated list (22) to one of the two groups (with and without virtual reality glasses). Allocation was performed by using permuted block technique, where participants were allocated in blocks of 4 and the allocation ratio was intended to be equal. Allocation was performed by a trial independent individual (23). Neither the operator nor the participant were blind to the intervention. Only the statistician was blind.

\section{Sample size}

The sample size was calculated on a study aimed to evaluate disease dynamics, treatment results, and frequency of malignant transformation of oral lichen planus (24).

A sample size of 15 patients per group (number of groups $=2$ ) (total sample size $=30$ patients) was the enough required sample for a pilot study, if the aim of a pilot study was to demonstrate intervention efficacy in two groups (25).

\section{Intervention}

-Calculus and all sources of traumatic irritation were removed.
- All patients were instructed about proper oral hygiene procedures.

- All patients will be evaluated for Stress Level using ISMAUK Stress Questionnaire (21) which was translated to the Arabic language through IBI (International British Institute-Alexandria) to help participants to understand the questions.

Diagnosis of erosive OLP was based on:

1-Histroy: including name, age, sex, disease onset, stress, medical history, drug history and previous treatment.

2-Clinical Examination: including examination of all clinical signs of EOLP and distribution of the lesions was done.

3-Histopathological examination: An Incisional biopsy was obtained from the area most representative of the lesion under local anesthesia using blade number 15. All biopsies were then fixed in 10\% neutral buffered formalin ( $\mathrm{pH} 7.0$ ) for at least 24 hours, and then sent to laboratory of Oral Pathology Department Faculty of Dentistry Alexandria University for staining and histological examination.

\section{Clinical evaluation:}

Oral lesions were evaluated clinically at baseline treatment, one month and three months after treatment. A periodontal probe was used as a ruler to measure the most represented area of each EOLP lesion. The response to treatment was measured according to the reduction in clinical signs and symptoms using:

\section{Subjective assessment}

Discomfort, pain and response to therapy was be reported by each patient via using Visual Analogue Scale (VAS) (20). The VAS was represented as a plain horizontal $10 \mathrm{~cm}$ line. Patients were instructed to bisect the line at a point coinciding to their present discomfort. A zero value equated to being pain free, whereas the most severe pain they have experienced was rated 10 .

2. Objective assessment

The lesions were evaluated by visual examination using the criteria set by Thongprasom et al, (2003) (26) where:

- Score 0: No lesion/normal mucosa.

- Score 1: Mild white striae only.

- Score 2: White striae with erythematous area $<1 \mathrm{~cm} 2$.

- Score 3: White striae with erythematous area $>1 \mathrm{~cm} 2$.

- Score 4: White striae with erosive area $<1 \mathrm{~cm} 2$.

- Score 5: White striae with erosive area $>1 \mathrm{~cm} 2$.

In addition, clinical photographs were taken of all EOLP lesions clinically at baseline, one month and three months after treatment using a digital camera.

\section{Statistical analysis}

Normality was checked for all variables using box plots and Kolmogorov-Smirnov test of normality. All variables showed non-normal distribution so mean, standard deviation, median and interquartile range (IQR) were used for data description. Comparing the two groups at each time point was done using Mann Whitney test. Comparing the baseline with first and third months in the same group was done using Friedman Test with post-hoc. Significance was set at $\mathrm{P} \leq 0.05$. Data was analyzed using IBM Statistical Package for Social Science SPSS/version 23 software (2015).

\section{RESULTS}

Thirty patients (20 females and 10 males) clinically and histopathologically diagnosed as having erosive OLP were 
enrolled in this study. The buccal mucosa was the most common site of involvement and the other sites were the tongue, palate and vermilion border of the lip. Patients were divided into two equal groups [15 patients per treatment group]. Patients of the control group received topical corticosteroids (kenacort in orabase) two to three times a day during the first three weeks followed by tapering the following nine weeks until a maintenance dose of two to three times a week was reached and topical antifungal (Miconaz oral gel) was also applied three to four times daily for three weeks, Patients of the test group received Glutamine capsules in a dosage of one capsule (750mg=0.75g) three times daily(2.25g/d) on an empty stomach for one month in combination with topical corticosteroid plus antifungal. All patients had visits for clinical evaluation after one and three months. Subjective and objective assessments were recorded at each visit. All patients complied with follow up visits.

Table [1] shows demographic characteristics of patients regarding age and gender. Each group included five males and ten females. On comparing the two studied groups regarding gender, it was found that there was no significant difference between the two studied groups $(p=1.000)$. The age in the control group was ranged from $40-66$ years with a mean of $51.27 \pm 7.81$, and in the test group the age ranged from $30-60$ years with a mean of $46.13 \pm 8.84$, there was no statistically significant difference between the two studied groups regarding age $(\mathrm{p}=0.150)$.

Table (1): Demographic data of the two study groups

\begin{tabular}{||c|c|c|c||}
\hline & $\begin{array}{c}\text { Control } \\
\mathbf{n = 1 5}\end{array}$ & $\begin{array}{c}\text { Test } \\
\mathbf{n = 1 5}\end{array}$ & P value \\
\hline Age(years) & & & \\
(Min-Max) & $40.00-66.00$ & $30.00-$ & \\
(Mean \pm SD) & $51.27 \pm 7.81$ & 60.00 & $\mathrm{Z}_{(\mathrm{MW})}=1.441$ \\
Median (IQR) & 50.00 & $46.13 \pm 8.84$ & $p=0.150 \mathrm{NS}$ \\
& $(45.00-$ & 45.00 & \\
& $60.00)$ & $(40.00-$ & \\
& & $53.00)$ & \\
\hline Gender & & $5(33.33 \%)$ & $\square^{2}(\mathrm{df}=1)=0.000$ \\
Male n=10 & $5(33.33 \%)$ & 10 & $p=1.000 \mathrm{NS}$ \\
$(100 \%)$ & $10(66.67 \%)$ & $(66.67 \%)$ & \\
Female & & & \\
n=20 & & & \\
$(100 \%)$ & & & \\
\hline
\end{tabular}

X2: Pearson Chi-Square test

df: degree of freedom

MW: Mann-Whitney U test

NS: Statistically not significant $(\mathrm{p}>0.05)$

\section{Clinical results}

1-Regarding VAS: Table [2] and figure [1] are showing the comparison between the two studied groups regarding the pain score VAS. The test group showed significantly less pain $\left(\mathrm{p}=0.001^{*}\right)$ at the first month follow up, However there was no statistically significant difference between the 2 groups at both baseline and third month follow-up.

2-Regarding Lesion size: Table [3] and figure [2] are showing the comparison between the two studied groups regarding the lesion size score according to Thongprasom et al., (2003) (28) and there was no statistically significant difference at baseline, first and at third months of followup.
Table (2): Comparison between the two study groups regarding the mean pain score (VAS).

\begin{tabular}{|c|c|c|c|}
\hline & Control & Test & $\begin{array}{c}\text { Test of } \\
\text { significance } \\
p \text { value }\end{array}$ \\
\hline $\begin{array}{l}\text { VAS at Baseline } \\
\text {-Mean } \pm \text { Std. } \\
\text { Deviation } \\
\text {-95\% CI for mean } \\
\text {-Median (IQR) }\end{array}$ & $\begin{array}{c}9.20 \pm 0.86 \\
8.7227-9.6773 \\
9.00^{\mathrm{a}}(8.00- \\
10.00) \\
\end{array}$ & $\begin{array}{c}9.07 \pm 0.88 \\
8.5773-9.5561 \\
9.00^{\mathrm{a}}(8.00- \\
10.00)\end{array}$ & $\begin{array}{l}\mathrm{Z}_{(\mathrm{MW})}=0.422 \\
p=0.673 \mathrm{NS}\end{array}$ \\
\hline $\begin{array}{l}\text { VAS at First } \\
\text { month } \\
\text {-Mean } \pm \text { Std. } \\
\text { Deviation } \\
\text {-95\% CI for mean } \\
\text {-Median (IQR) } \\
\end{array}$ & $\begin{array}{c}4.60 \pm 1.12 \\
3.9791-5.2209 \\
5.00^{\text {b.c }}(4.00- \\
6.00)\end{array}$ & $\begin{array}{c}2.87 \pm 1.36 \\
2.1159-3.6175 \\
3.00^{\text {b.c }}(2.00- \\
4.00)\end{array}$ & $\begin{array}{c}\mathrm{Z}_{(\mathrm{MW})}=3.209 \\
p=0.001^{*}\end{array}$ \\
\hline $\begin{array}{l}\text { VAS at Third } \\
\text { month } \\
\text {-Mean } \pm \text { Std. } \\
\text { Deviation } \\
\text {-95\% CI for mean } \\
\text {-Median (IQR) } \\
\end{array}$ & $\begin{array}{c}2.60 \pm 1.80 \\
1.6006-3.5994 \\
3.00^{\text {b.c }}(0.00- \\
4.00)\end{array}$ & $\begin{array}{c}1.67 \pm 1.63 \\
0.7623-2.5710 \\
3.00^{\text {b.c }}(0.00- \\
3.00)\end{array}$ & $\begin{array}{l}\mathrm{Z}_{(\mathrm{MW})}=1.521 \\
p=0.128 \mathrm{NS}\end{array}$ \\
\hline $\begin{array}{l}\text { Test of } \\
\text { significance } \\
\text { Friedman Test } \\
p \text { value } \\
\end{array}$ & $\begin{array}{c}\mathrm{X}^{2}(\mathrm{Fr})(\mathrm{df}=2)=28 \\
737 \\
p=0.000 *\end{array}$ & $\begin{array}{c}\mathrm{X}^{2}{ }_{(\mathrm{Fr})(\mathrm{df}=2)}=28 \\
182 \\
p=0.000^{*}\end{array}$ & \\
\hline
\end{tabular}

CI: Confidence interval

IQR: Inter-quartile range

MW: Mann-Whitney U test

$\mathrm{df}=$ degree of freedom

Different superscript letters indicate statistically significant difference (using Dunn-Sidek method)

*: Statistically significant $(\mathrm{p}<0.05)$

NS: Statistically not significant $(\mathrm{p}>0.05)$

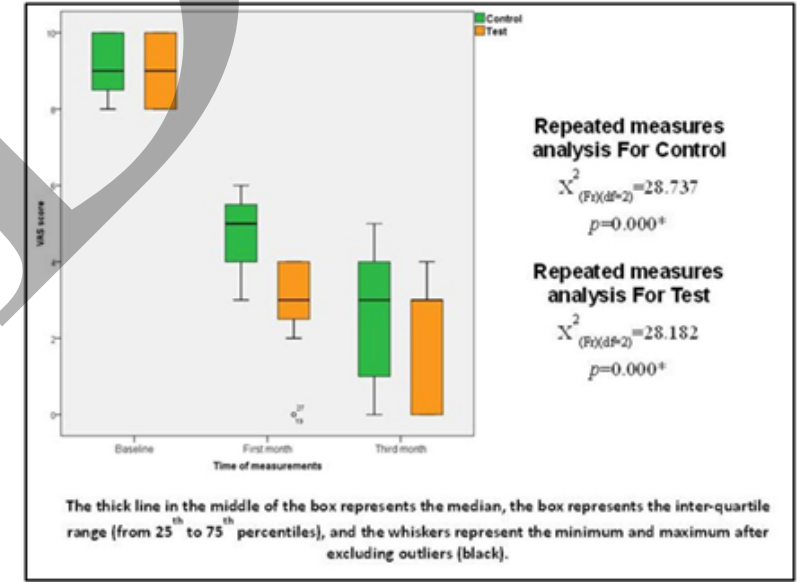

Figure (1): Box and whisker graph of VAS score in the studied groups.

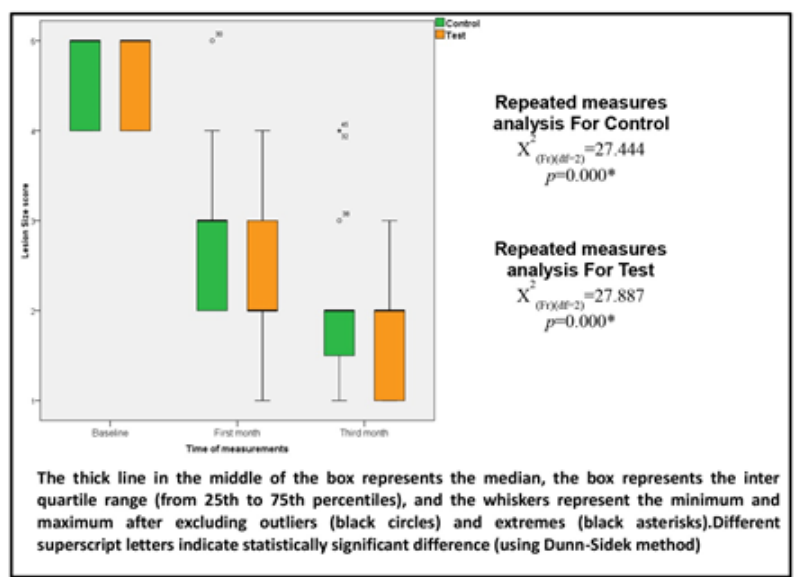

Figure (2): Box and whisker graph of lesion size score in the studied groups. 
Table (3): Comparison between the two study groups regarding lesion size score

\begin{tabular}{|c|c|c|c|}
\hline & Control & Test & $\begin{array}{c}\text { Test of } \\
\text { significance } \\
p \text { value }\end{array}$ \\
\hline $\begin{array}{l}\text { Lesion Size score } \\
\text { at Baseline } \\
\text {-Mean } \pm \text { Std. } \\
\text { Deviation } \\
-95 \% \text { CI for mean } \\
\text {-Median (IQR) }\end{array}$ & $\begin{array}{c}4.53 \pm 0.52 \\
4.2474-4.8193 \\
5.00^{\mathrm{a}}(4.00- \\
5.00)\end{array}$ & $\begin{array}{c}4.53 \pm 0.52 \\
4.2474- \\
4.8193 \\
5.00^{\mathrm{a}}(4.00- \\
5.00)\end{array}$ & $\begin{array}{l}\mathrm{Z}_{(\mathrm{MW})}=0.000 \\
p=1.000 \mathrm{NS}\end{array}$ \\
\hline $\begin{array}{l}\text { Lesion Size score } \\
\text { at First month } \\
\text {-Mean } \pm \text { Std. } \\
\text { Deviation } \\
-95 \% \text { CI for mean } \\
\text {-Median (IQR) }\end{array}$ & $\begin{array}{c}2.87 \pm 0.92 \\
2.3597-3.3736 \\
3.00^{\text {b.c }}(2.00- \\
3.00)\end{array}$ & $\begin{array}{c}2.27 \pm 0.80 \\
1.8243- \\
2.7090 \\
2.00^{\text {b.c }}(2.00- \\
3.00)\end{array}$ & $\begin{array}{c}\mathrm{Z}_{(\mathrm{MW})}=1.766 \\
p=0.077 \mathrm{NS}\end{array}$ \\
\hline $\begin{array}{l}\text { Lesion Size score } \\
\text { at Third month } \\
\text {-Mean } \pm \text { Std. } \\
\text { Deviation } \\
-95 \% \text { CI for mean } \\
\text {-Median (IQR) }\end{array}$ & $\begin{array}{c}2.07 \pm 0.96 \\
1.5344-2.5989 \\
2.00^{\text {b.c }}(1.00- \\
2.00)\end{array}$ & $\begin{array}{c}1.67 \pm 0.72 \\
1.2659- \\
2.0675 \\
2.00^{\text {b.c }}(1.00- \\
2.00)\end{array}$ & $\begin{array}{c}\mathrm{Z}_{(\mathrm{MW})}=1.148 \\
p=0.251 \mathrm{NS}\end{array}$ \\
\hline $\begin{array}{ll}\text { Test } & \text { of } \\
\text { significance } & \\
\text { Friedman Test } & \\
p \text { value } & \end{array}$ & $\begin{array}{c}\mathrm{X}_{(\mathrm{Fr})(\mathrm{df}=2)}=27.4 \\
44 \\
p=0.000 *\end{array}$ & $\begin{array}{c}\mathrm{X}_{(\mathrm{Fr})(\mathrm{df}=2)}=27 . \\
887 \\
p=0.000 *\end{array}$ & \\
\hline
\end{tabular}

CI: Confidence interval

IQR: Inter-quartile range

MW: Mann-Whitney U test

$\mathrm{df}=$ degree of freedom

Different superscript letters indicate statistically significant difference (using Dunn-Sidek method)

* : Statistically significant $(\mathrm{p}<0.05)$

NS: Statistically not significant $(\mathrm{p}>0.05)$

\section{DISCUSSION}

Oral lichen planus (OLP) is generally accepted as a chronic inflammatory disease of squamous epithelium with an unclear etiopathogenesis (3). In our clinical study, 20 females and 10 males were clinically and histopathologically diagnosed as EOLP. Those finding were in agreement with other reports that have shown a female predilection to this condition $(4,27)$, On the other hand Abdullah et al., (28) stated that both sexes are almost equally affected by lichen planus. The ages of enrolled individuals ranged between 30 and 60years; this range was in accordance with Bilgili et al., (29) and Al Hashimi et al., (30). While in other studies lichen planus was noted in childhood $(31,32)$. However, in the present study, gender and age distribution had no statistically significant differences between the two studied groups.

Lichen planus may be precipitated or exacerbated by psychosocial stressors (33). However, Chiappelli et al., (34); stated that there is still controversy concerning the role of stress as a major or minor etiologic factor in the pathogenicity of lichen planus. Therefore, it seemed beneficial in this present study to evaluate the stress state of enrolled individuals by using ISMA-UK stress questionnaire (21). In the present study, both groups applied: trimicolone acetonide (kenacort) (16) and topical antifungal (Miconaz oral gel) (17). The use of the antifungal oral gel was to avoid the occurrence of oral candidiasis; this was in accordance with Lodi et al., (17) who compared clobetasol gel with and without Miconazole gel application in OLP patients. There were no clinical signs of oral candidiasis in patients who applied Miconazole, while 30\% of patients who were treated only with steroids were affected.

In this clinical trial Gln supplement was used as an adjunctive to the corticosteroid and antifungal therapy in the treatment of EOLP. This was supported by Newsholme (35) who proposed that Gln is an important regulator for immune responses, while Heyland et al., (36) stated that Gln supplementation has no therapeutic benefits.

In this study, Gln supplement was given in dosage of $2.25 \mathrm{~g} / \mathrm{d}$ for 1 month. This was supported by Holecek (37) who stated that Gln supplementation doses range from 2-40 g/d for healthy individuals, While Candow et al., (38) stated that relevant human clinical trials involved oral Gln doses ranging from 3 to $45 \mathrm{~g} / \mathrm{d}$ and the highest oral Gln dose utilized in a published human clinical trial was up to $45 \mathrm{~g} / \mathrm{d}$ for 6 weeks in healthy adults.

On comparison between the two studied groups at each point of time regarding the pain score (VAS), there was significantly less pain in the test group at first month and no statistical significance at baseline and at third month when compared to control group. This reflects the effectiveness of Gln supplementation that was prescribed for one month as adjunctive to the conventional therapy in the treatment of EOLP. This result is in a line with evidence from previous studies $(35,39)$ demonstrating the role of L-glutamine administration in attenuating the excessive production of cytokines, such TNF-alpha and their effects, protecting against a variety of cell/tissue injuries or insults, production of glutathione (GSH) and specific transcription factor NFkB (Nuclear factor kappa-light-chain-enhancer of activated B cells) and improving the outcome for critically ill patients and post-surgically. Moreover, this result was in consort with the results of Son et al., (40), who concluded that Gln has antidepressive effects through increments of glutamate and glutamine levels and glutamatergic activity on the medial prefrontal cortex.

However, comparison between the two groups regarding lesion size score showed that there was no statistically significant difference among the three different times of measurement. The possible explanation may be due to the systemic use of GIn in present study that had minimal or no effect on oral mucosal tissues in situ. This is in a line with Heyland et al., (36), who concluded that glutamine did not improve clinical outcomes among critically ill patients.

\section{CONCLUSION}

The results of this study revealed that glutamine supplement as adjunctive to topical corticosteroid appears to be significantly more effective in the control of the symptoms of EOLP when compared to topically applied corticosteroid. However, it has no effect on the clinical signs (lesion size) of the disease.

\section{CONFLICT OF INTEREST}

The authors declare that they have no conflicts of interest.

\section{REFERENCES}

1-Scully C, Beyli M, Ferreiro MC, Ficarra G, Gill Y, Griffiths $\mathrm{M}$, et al. Update on oral lichen planus: etiopathogenesis and management. Crit Rev Oral Biol Med. 1998;9:86-122. 
2-Payeras MR, Cherubini K, Figueiredo MA, Salum FG. Oral lichen planus: focus on etiopathogenesis. Arch Oral Biol. 2013;58:1057-69.

3-Eisen D, Carrozzo M, Bagan Sebastian JV, Thongprasom K. Number V Oral lichen planus: clinical features and management. Oral Dis. 2005;11:338-49

4-Sugerman PB, Savage NW, Walsh LJ, Zhao ZZ, Zhou XJ, Khan A, et al. The pathogenesis of oral lichen planus. Crit Rev Oral Biol Med. 2002;13:350-65.

5-Gupta S, Jawanda MK. Oral Lichen planus: An Update on Etiology, Pathogenesis, Clinical Presentation, Diagnosis and Management. Indian J. Dermatol. 2015; 60 : 222-29.

6-Lodi G, Scully C, Carrozzo M, Griffiths M, Sugerman PB, Thongprasom K. Current controversies in oral lichen planus: report of an international consensus meeting. Part 1. Viral infections and etiopathogenesis. Oral Surg Oral Med Oral Pathol Oral Radiol Endod. 2005;100:40-51.

7-Thornhill M. The current understanding of the aetiology of oral lichen planus. Oral Dis. 2010;16:507-8.

8-Anshumalee N, Shashikanth M, Sharma S. Oxidative stress and oral lichen planus: A possible association. Cusp. 2007;4:31-4.

9-Sezer E, Ozugurlu F, Ozyurt H, Sahin S, Etikan I. Lipid peroxidation and antioxidant status in lichen planus. Clin Exp Dermatol. 2007;32:430-4.

10-Karthikeyan P, Aswath N. Stress as an Etiologic Co-Factor in Recurrent Aphthous Ulcers and Oral Lichen planus. J Oral Sci. 2016;58:237-40.

11-Kanwar AJ, De D. Lichen planus in children. Indian J Dermatol Venereol Leprol. 2010;76:366-72.

12-Magin PJ, Pond CD, Smith WT, Watson AB, Goode SM. A cross-sectional study of psychological morbidity in patients with acne, psoriasis and atopic dermatitis in specialist dermatology and general practices. J Eur Acad Dermatol Venereol. 2008;22:1435-44.

13-Rezaei R, Wang WW, Wu ZL, Dai Z, Wang J, Wu G. Biochemical and Physiological Bases for Utilization of Dietary Amino Acids by Young Pigs. J Anim Sci Biotechnol. 2013;4:7.

14-Wischmeyer PE. Glutamine and Heat Shock Protein Expression. Nutrition. 2002;18:225-8.

15-Belal MH. Management of Symptomatic ErosiveUlcerative Lesions of Oral Lichen planus in an Adult Egyptian Population Using Selenium-ACE Combined with Topical Corticosteroids plus Antifungal Agent. Contemp Clin Dent. 2015;6:454-60.

16-Glick M. Burket's Oral Medicine. 12th ed. Shelton, Connecticut: People's Medical Publishing House USA; 2015.

17-Lodi G, Tarozzi M, Sardella A, Demarosi F, Canegallo L, Di Benedetto D, et al. Miconazole as adjuvant therapy for oral lichen planus: a double-blind randomized controlled trial. Br J Dermatol. 2007;156:1336-41.

18-Inaba M, Terai H, Nakajima Y, Fukui N, Suwa Y, Yamamoto $\mathrm{K}$, et al. Usefulness of oral administration of the specialized amino acid supplement consisting of $\beta$ hydroxy- $\beta$-methylbutyrate, L-arginine and L-glutamine (Abound ${ }^{\mathrm{TM}}$ ) for chronic soft tissue diseases in the mouth. SDRP J Food Sci Technol. 2016;123-7.

19-Van der Meij EH, Van der Waal I. Lack of clinicopathologic correlation in the diagnosis of Oral Lichen planus based on the presently available diagnostic criteria and suggestions for modifications. J Oral Pathol Med 2003;32: 507-12.
20-Scott J, Huskisson EC. Graphic representation of pain. Pain. 1976;2:175-84.

21-ISMA-UK International Stress Management Association. 2013. Available at: http://isma.org.uk/wpcontent/uploads/2013/08/Stress-Questionnaire.pdf.

22-Saghaei M. Random Allocation Software [Internet]. 2004 [cited 2019 Apr 25]. Avaliable form: http://mahmoodsaghaei.tripod.com/Softwares/randalloc.ht $\mathrm{ml}$

23-Saghaei M. Random Allocation Software for Parallel Group Randomized Trials. 2004;6;1-6

24-Kaplan I, Ventura-Sharabi Y, Gal G, Calderon S, Anavi Y. The dynamics of oral lichen planus: A retrospective clinicopathological study. Head Neck Pathol 2012; 6: 178-83.

25-Hertzog MA. Considerations in determining sample size for pilot studies. Research in nursing and health. 2008; 31:180-91.

26-Thongprasom K, Luengvisut P, Wongwatanakij A, Boonjatturus C. Clinical Evaluation in Treatment of Oral Lichen planus with Topical Fluocinolone Acetonide: A 2 Year Follow-Up. J Oral PatholMed. 2003;32:315-22.

27-Kyriakis KP, Terzoudi S, Palamaras I, Michailides C, Emmanuelidis S, Pagana G. Sex and Age Distribution of Patients with Lichen planus. J Eur Aca. Dermatol Venereol. 2006;20:625-6.

28-Abdullah SA, Maaita TJ. Epidemiological and Clinical Features of Lichen planus Injordanian Patients. Pak J Med Sci. 2007;23:92-4.

29-Bilgili SG, Karadag AS, Ozkol HU, Calka O, Akdeniz N. The prevalence of skin diseases among the geriatric patients in Eastern Turkey. J Pak Med Assoc. 2012;62:535-9.

30-Al-Hashimi I, Schifter M, Lockhart PB, Wray D, Brennan M, Migliorati, CA, et al. Oral Lichen planus and Oral Lichenoid Lesions: Diagnostic and Therapeutic Considerations. Oral Surg Oral Med Oral Pathol Oral Radiol Endod. 2007;103:e21-12.

31-Pandhi D, Singal A, Bhattacharya SN. Lichen planus in Childhood: A Series of 316 Patients. Pediatr Dermatol. 2014;31:59-67.

32-Kanwar AJ, De D. Lichen planus in Childhood: Report of 100 Cases. Clin Exp Dermatol. 2010;35:257-62.

33-Tawil M, Sediki, N, Hassan H. Psychobiological Aspects of Patients with Lichen Planus. Curr Psychiatry. 2009;16:370-80.

34-Chiappelli F, Cajulis OS. Psychobiologic Views on StressRelated Oral Ulcers. Quintessence Int. 2004;35:223-7.

35-Newsholme P. Why Is L-Glutamine Metabolism Important to Cells of the Immune System in Health, Postinjury, Surgery or Infection? J Nutr. 2001;131:2515S-222S; discussion 23S-4S.

36-Heyland D, Muscedere J, Wischmeyer PE, Cook D, Jones G, Albert M, et al. Canadian Critical Care Trials Group A Randomized Trial of Glutamine and Antioxidants in Critically Ill Patients. N Engl J Med. 2013;368:1489-97.

37-Holecek M. Side Effects of Long-Term Glutamine Supplementation. J Parenter EnterNutr. 2013;37:607-16.

38-Candow DG, Chilibeck PD, Burke DG, Davison KS, SmithPalmer T. Effect of Glutamine Supplementation Combined 
with Resistance Training in Young Adults. Eur J Appl Physiol. 2001;86:142-9.

39-Garrett-Cox RG, Stefanutti G, Booth C, Klein NJ, Pierro A, Eaton S. Glutamine Decreases Inflammation in Infant Rat Endotoxemia. J Pediatr Surg. 2009;44:523-9.
40-Son H, Baek JH, Go BS, Jung DH, Sontakke SB, Chung HJ, et al. Glutamine Has Antidepressive Effects Through Increments of Glutamate and Glutamine Levels and Glutamatergic Activity in the Medial Prefrontal Cortex. Neuropharmacology. 2018;143:143-52.

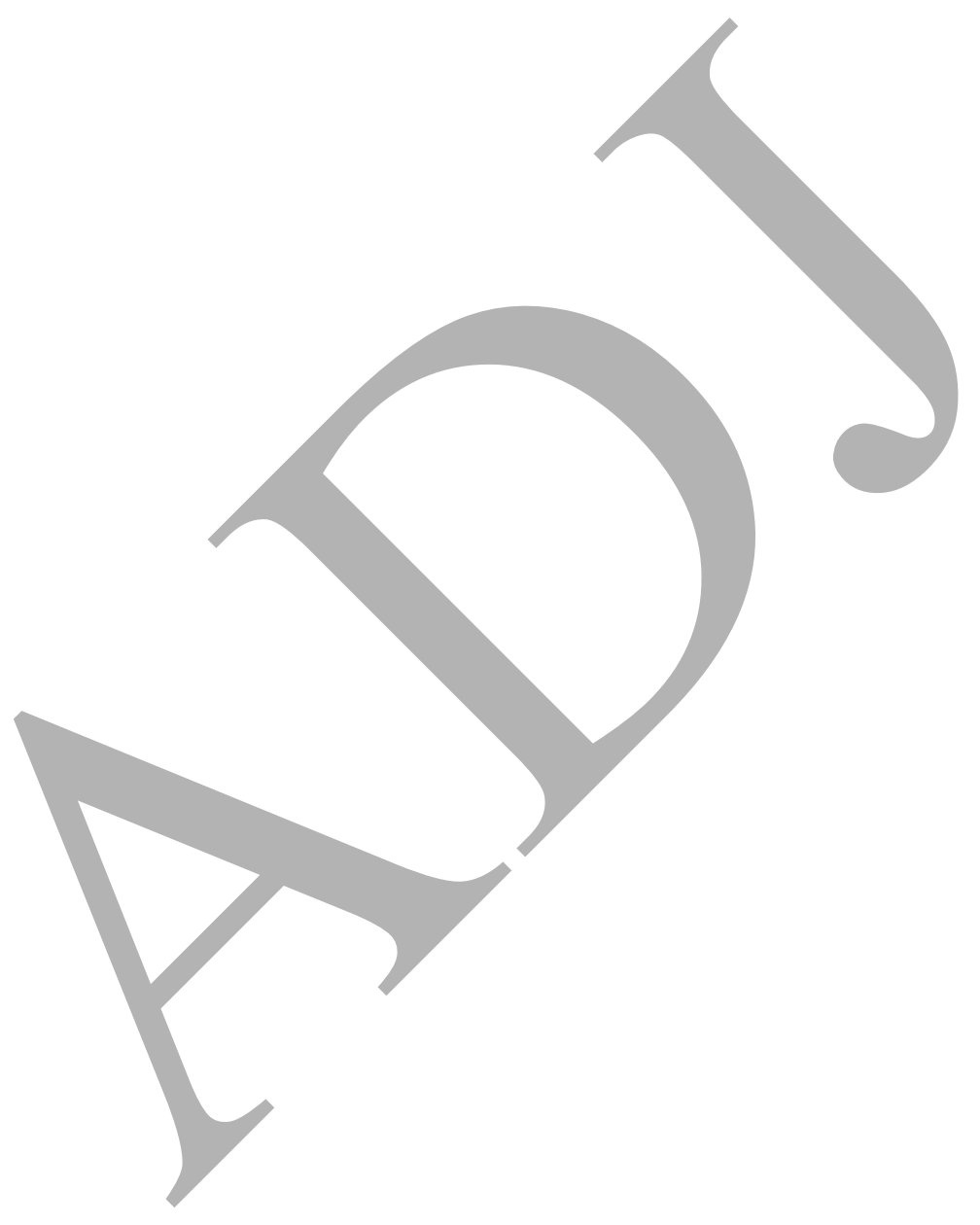

